\section{$\underset{\substack{\text { hommes } \\ \text { \& migrations }}}{ }$}

\section{Hommes \& migrations}

Revue française de référence sur les dynamiques

migratoires

$1314 \mid 2016$

Migrations chinoises et générations

\title{
In Jackson Heights
}

Film américain de Frédérick Wiseman

\section{Anaïs Vincent}

\section{Q OpenEdition \\ 1 Journals}

\section{Édition électronique}

URL : http://journals.openedition.org/hommesmigrations/3672

DOI : 10.4000/hommesmigrations.3672

ISSN : 2262-3353

\section{Éditeur}

Musée national de l'histoire de l'immigration

\section{Édition imprimée}

Date de publication : 1 avril 2016

Pagination : 173

ISBN : 978-2-919040-35-3

ISSN : $1142-852 X$

\section{Référence électronique}

Anaïs Vincent, «In Jackson Heights », Hommes \& migrations [En ligne], 1314 | 2016, mis en ligne le 19 septembre 2016, consulté le 24 septembre 2020. URL : http://journals.openedition.org/

hommesmigrations/3672; DOI : https://doi.org/10.4000/hommesmigrations.3672 
